\title{
Cooperative Model in Language Reasoning: Indonesian Language Teaching Materials in Teacher Training and Education Faculty of Muhammadiyah Sumatera Utara University
}

\author{
Tepu Sitepu \\ University of Muhammadiyah Sumatera Utara, Indonesia \\ Email: tepusitepu61@gmail.com
}

\begin{abstract}
The aim of this study is to determine student's language reasoning of Mathematics Education and Accounting Education in Teaching Training and Education Faculty of Muhammadiyah Sumatera Utara University. The research method used is an experimental method, where Mathematics Education as a control class or without using cooperative models and Accounting Education as a class experiment or use a cooperative learning models. The sample of this study is 65 students consisting of Mathematics Education students as many as 40 students, Accounting Education students as many as 25 students. Research results on Mathematics Education students through tests without using cooperative learning models obtained Mean= 73.50. Research results on Accounting Education through tests after using cooperative learning models obtained Mean $=76.20$. Hypothesis tests conducted by statistical test or t test, it is obtained $t_{\text {count }}=1.78$ and $t_{\text {table }}=1.68$. Thus, $t_{\text {count }}$ is greater than $t_{\text {table, }}$ it can be concluded that cooperative models applied to Accounting Education in learning can improve student's language reasoning.
\end{abstract}

Keywords: cooperative; reasoning; language; teaching materials

\section{Introduction}

It is possible that there is a mistaken assumption that concentration on increasing epistemic level literacy through lectures on writing theories in Indonesian Language study program and lectures on General Courses (MKU) of Indonesian Language at the non-language faculties of a university is certain to turn students into writer productive graduates. Many college graduates have the ability to read but are not matched by the ability to write. This phenomenon has long existed in Indonesian universities, but the majority of lecturers and or campus bureaucrats are less responsive to it. Even though this is a paradox in Indonesian Language education in Indonesia.

The most effective medicine for treating the above phenomenon is repositioning and redefining general courses of Indonesian Language in all tertiary institutions. General courses of Indonesian Language must be given new blood in order to be able to increase epistemic literacy of students. There are four approaches that can be taken simultaneously according to Alwasilah (2010: 77) that are curricular approach by repositioning it as a compulsory subject with a number of Semester Credit Units (SKS) that vary according to student needs, extracurricular approach by involving students in a number of extra activities to support student abilities; epistemological approach that is by aligning the nature of the General Course with epistemic literacy demands and functional or cultural approaches in the selection of teaching materials as a General Course.

We have often heard that we are more cultured to hear-say than to read-write. Language education including general courses of Indonesian Language must be oriented towards literacy development and leave oral domination. Language education should be oriented to the competence of language skills rather than performance theoretical knowledge about language. 
Professionals are required to make decisions based on the results of research, not the results of personal subjective experience or knowledge from inspiration. The same applies to writing education, especially writing scientific papers. The weakness of academic writing skills and the low number of publications in higher education has been due various factors: cultural, social, and curricular. At the tertiary level, it is time to reorganize and reposition lectures in general courses of Indonesian Language with orientation to the acquisition of academic writing skills.

In academic writing or scientific writing, language and/or logic reasoning is indispensable. Both inductive and deductive reasoning. These are the background of researchers for researching language reasoning as teaching materials for general courses of Indonesian Language at Muhammadiyah Sumatera Utara University, especially Faculty of Teacher Training and Education.

Based on the above background, the formulation of the problem in this study are how the language reasoning ability of Mathematics Education students in semester 4 of academic year 2018-2019 in Faculty of Teacher Training and Education of Muhammadiyah Sumatera Utara University without the application of cooperative learning models and how is the language reasoning ability of Accounting Education students semester 4 of academic year 2018-2019 in Faculty of Teacher Training and Education of University of Muhammadiyah Sumatera Utara University by applying cooperative learning models and is there any effect of the application of cooperative learning models in improving student language reasoning.

This study generally aims to determine student's language reasoning ability of Muhammadiyah Sumatera Utara University. Specifically this study aims to obtain the truth of student's language reasoning ability in Mathematics and Accounting Education in the 4th semester of academic year 2018-2019 Faculty of Teacher Training and Education. Thus, it can be taken an important policy whether or not teaching material of language reasoning in the context of writing scientific papers in Indonesian language subject as a General Course in higher education. And also innovation in learning courses or innovation in the development of science and technology.

\section{Review of Literature}

\subsection{Scientific Knowledge}

Epistemology is a branch of philosophy that discusses human knowledge which includes the sources, character and truth of human knowledge. Based on the analysis of the basic problems of epistemology, the sources of human knowledge include: a priori knowledge and a priori knowledge. A priori knowledge is knowledge obtained by looking at the real state of this nature. Whereas apostolic knowledge is knowledge acquired through reasoning considerations based on cause to effect, from specific to general, based on observations and empirical. All this human knowledge can only be expressed through language (Djojosuroto, 2010: 129).

Scientific knowledge is a type of knowledge that is obtained and accounted for scientifically or by applying scientific methods. While the scientific method is a procedure or systematic steps that need to be taken in order to obtain knowledge based on sensory perception and involves testing hypotheses and theories in a controlled manner. Scientific knowledge does not automatically appear when we observe the environment around us. Generally, we ask questions about this world. Questions direct our investigation. Accuracy in asking questions is a decisive initial step in the process of inquiry. Clear questions lead us to be well-positioned to 
formulate hypotheses. Hypotheses are the raw material for scientific knowledge (Sudarminta, 2009: 166).

Aposteori knowledge as stated above can be obtained through induction reasoning and deduction reasoning. Induction reasoning is done through the steps of observing the problem situation, submitting hypotheses, field research, testing hypotheses and drawing conclusions. While deduction reasoning ends with the formulation of predictions drawn by logical from the explanatory hypothesis. That is, deduction reasoning stops with predictions in the form of if-then (Keraf, 2009: 108).

\subsection{Writing Scientific Work}

Scientific work has the characteristics of: objective, impartial, based on facts, systematic and logical. Furthermore, scientific work based on reasoning is distinguished from: inductive and deductive scientific work. And the core part of scientific work consists of the introduction, the main text or main ideas which will be discussed and the concluding section. In the introduction section general things are presented whose function shows the reader why they are discussing, what problems are discussed and what are the expectations of the discussion. That is, the introduction contains about: the background of the problem, the limitations and purpose of the writing. The main text section contains topics of scientific work. The concluding section contains conclusions and suggestions (Suyitno, 2011: 87).

As with other scientific papers, writing a paper through the stages of choosing a topic, determining the purpose of writing, setting a thesis, making a framework. Choosing a topic topic must be an interesting and most preferred topic. The topic specified is not too broad. The purpose of the paper can be to convince the reader to support or explaining the topic. Thesis is the merging of topics and objectives and the thesis reveals the topic and states the important points to be discussed. The establishment of a framework is the laying of ideas about the topic in an organized format (Wijayanti, 2017: 215).

In writing scientific papers, technically the language needs to be considered when writing direct or indirect quotations, writing reference lists, writing words, writing abbreviations, writing punctuation marks, using sentences, especially reasoning sentences. Reasonable reasoning is sentences whose contents are acceptable by common sense. That is, a sentence that is logical (Suyitno, 2011: 149).

\subsection{Inductive Reasoning}

Induction is a thought process that starts from one or a number of individual phenomena to derive a conclusion (inference). This reasoning process starts to move from research or evaluation of existing phenomena. Individual phenomena can be interpreted here as data and facts that are factual. Facts or statements (propositions) that have been verified.

Keraf (2008: 43) argues that there are several types of inductive reasoning, namely generalization, hypotheses and theories, analogies and causals. Generalization is a process of reasoning that departs from a number of individual phenomena to derive a general inference that covers all the phenomena earlier. For example:

Gold, a type of metal when heated will expand.

Silver, a type of metal when heated will expand.

Bronze, a type of metal when heated will expand.

Copper, a type of metal when heated will expand.

Iron, a type of metal when heated will expand. 
Conclusion: So, all types of metals when heated will expand.

Inductive analogy or logical analogy is a process of reasoning based on an actual similarity between two things. Based on the actual similarity, it can be concluded that because the two things contain similarities in certain things, then in other aspects are the same. For example:

Anisa is an alumni of Economics Faculty in the University of $\mathrm{X}$. She has given outstanding achievements to company $\mathrm{Y}$, where she works. She has proposed many ways to solve difficulties faced by the company. Bahar is an alumni of Economics Faculty in the University of $\mathrm{X}$. Conclusion: So, Bahar was accepted to work at company $\mathrm{Y}$.

Cause and effect depart from an event that is considered as a known cause and then moves towards a conclusion in the form of effect. For example:

Pressing the light switch (cause) caused the light to turn on.

Rain fell heavily (cause) caused flooding.

Lack of fertilizing plants (cause) caused in a failed harvest.

And Cause and effect is an inductive thought process that starts from an event that is considered as a known cause and then moves towards the causes. For example:

Pain in the patient's chest due to cancer.

Farmers' rice yields are reduced due to lack of irrigation.

Transportation costs rise due to rising fuel prices.

\subsection{Deductive Reasoning}

Deductive reasoning means a thought process that goes from an existing proposition to a new proposition in the form of a conclusion. There are general propositions, there are also special. Deductive knowledge is also called syllogism. In syllogism there are three propositions namely two propositions called major and minor premises and one proposition is called a conclusion or conclusion.

Keraf (2008: 58-74) argues that there are four types of deductive reasoning, there are categorical syllogism, hypothetical syllogism, alternative syllogism and entimem. Categorical syllogism consists of three propositions namely major premise, minor premise and conclusion, with mathematical formula:

PU: All A = B All students have many knowledge.

PK: $\quad \mathrm{C}=\mathrm{B}$ Anita is a student.

K: $\quad \mathrm{C}=\mathrm{B}$ Because of that, Anita has a lot of knowledge.

PU: All A = B All aircraft are motorized vehicles.

PK: $\quad \mathrm{B}=\mathrm{C}$ Motorized vehicles need fuel oil.

K: $\quad$ A $=$ C So airplanes need fuel oil.

PU: All A = B All students must comply with campus rules.

PK: $\quad$ C $\neq A \mathrm{Ki}$ Joko Bodo is not a student.

$\mathrm{K}$ : $\quad \mathrm{C} \neq \mathrm{B}$ So, Ki Joko Bodo doesn't have to obey the campus rules.

The syllogism of the hypothesis is deductive reasoning that starts from an opinion that there is no proposition in the proposition or does not occur. With a mathematical formula, if $\mathrm{P}$ then Q. For example:

If rains then the harvest will not fail.

It doesn't rain.

Therefore, the harvest failed. 
Alternative syllogism is deductive reasoning in which a major proposition is a choice, while the minor is a categorical proposition that accepts or rejects one alternative. For example: Mother is in the market or at home.

Mother is at home.

So, Mother not in the market.

Entimem is a short form of syllogism. That is, syllogism is only with two propositions, one of which is eliminated. Even if the proposition is omitted, it is still considered in the mind and is considered known by others. For example:

All lecturers have many knowledge.

Pak Said Siregar is a lecturer.

So, Mr. Said Siregar has a lot of knowledge.

The entimem: Mr. Said Siregar have a lot of knowledge because he is a lecturer.

\subsection{Model of Cooperative Learning}

Innovative learning is generally learning that is done in groups. Learning is done by increasing learning activities with a number of students in one group. Cooperative learning activities emphasize the awareness of students to help each other find and process information, apply knowledge and skills. In general- The success of a group is determined by the contribution of individuals in cooperative learning. Cooperative learning can be used to improve things.

Sani (2014: 97) suggests that a learning model is related to a particular learning theory. Based on the theory developed stages of learning. In other words, the learning model has syntaxsyntax is the stage in implementing the model in whatever activities need to be done by lecturers and students or students, starting the initial learning activities until the end of the activity.

The Model of Cooperative Learning which was implemented in line with the literature has given opportunities to the experimental group research participants to review what they had written together, i.e. peer criticism aids students sharpen their knowledge about essay structure and grammatical rules. It also provides the students with the chance of evaluating their own work, demonstrating more confidence in writing and decreasing their apprehensions towards learning writing skills (

Table 1. The syntax of cooperative learning models in general

\begin{tabular}{|l|l|}
\hline Phases & Lecturer Activity \\
\hline $\begin{array}{l}\text { Phase 1. Conveying the learning } \\
\text { objectives and motivating students }\end{array}$ & $\begin{array}{l}\text { Lecturers convey the learning objectives to be } \\
\text { achieved and motivate students to learn. }\end{array}$ \\
\hline $\begin{array}{l}\text { Phase 2. Deliver / present the } \\
\text { information }\end{array}$ & $\begin{array}{l}\text { Lecturers present information to students with } \\
\text { lectures or reading material. }\end{array}$ \\
\hline $\begin{array}{l}\text { Phase 3. Organizing students in study } \\
\text { groups }\end{array}$ & $\begin{array}{l}\text { The lecturer divides students into groups or } \\
\text { explains to students how to form study groups. }\end{array}$ \\
\hline $\begin{array}{l}\text { Phase 4. Guiding work and study } \\
\text { groups }\end{array}$ & $\begin{array}{l}\text { The lecturer guides the study groups as they work } \\
\text { on assignments. }\end{array}$ \\
\hline Phase 5. Evaluation & $\begin{array}{l}\text { The lecturer evaluates the learning outcomes or } \\
\text { each group presents their work. }\end{array}$ \\
\hline Phase 6. Give awards & $\begin{array}{l}\text { Lecturers assess and give appreciation for the } \\
\text { efforts and learning outcomes of individuals / } \\
\text { groups }\end{array}$ \\
\hline
\end{tabular}




\section{Research Method}

This study is an experimental research. Experimental research is an experimental design with each step of the action defined so that information related or needed for the problem to be examined is factually collected (Noor, 2012: 112). The design of this study is post-test only control group design. That is, there are two groups selected randomly, the first group is treated while the second group is not treated. The first group is given treatment, then measurements are taken, while the second group as the controller is not given treatment but only carried out measurements directly.

\subsection{Location and Time of Study}

This study was conducted in Mathematics Education and Accounting Education Study Program in Faculty of Teacher Training and Education of Muhammadiyah Sumatera Utara University, Jalan Kapten Muchtar Basri No.3 Medan. While the implementation of this study was conducted in the academic year 2018-2019 for General Courses of Indonesian Language semester 4, which is from February to July 2019.

\subsection{Study Process}

This study process uses Noor's research design model (2012: 116) as can be seen in the implementation as follows:

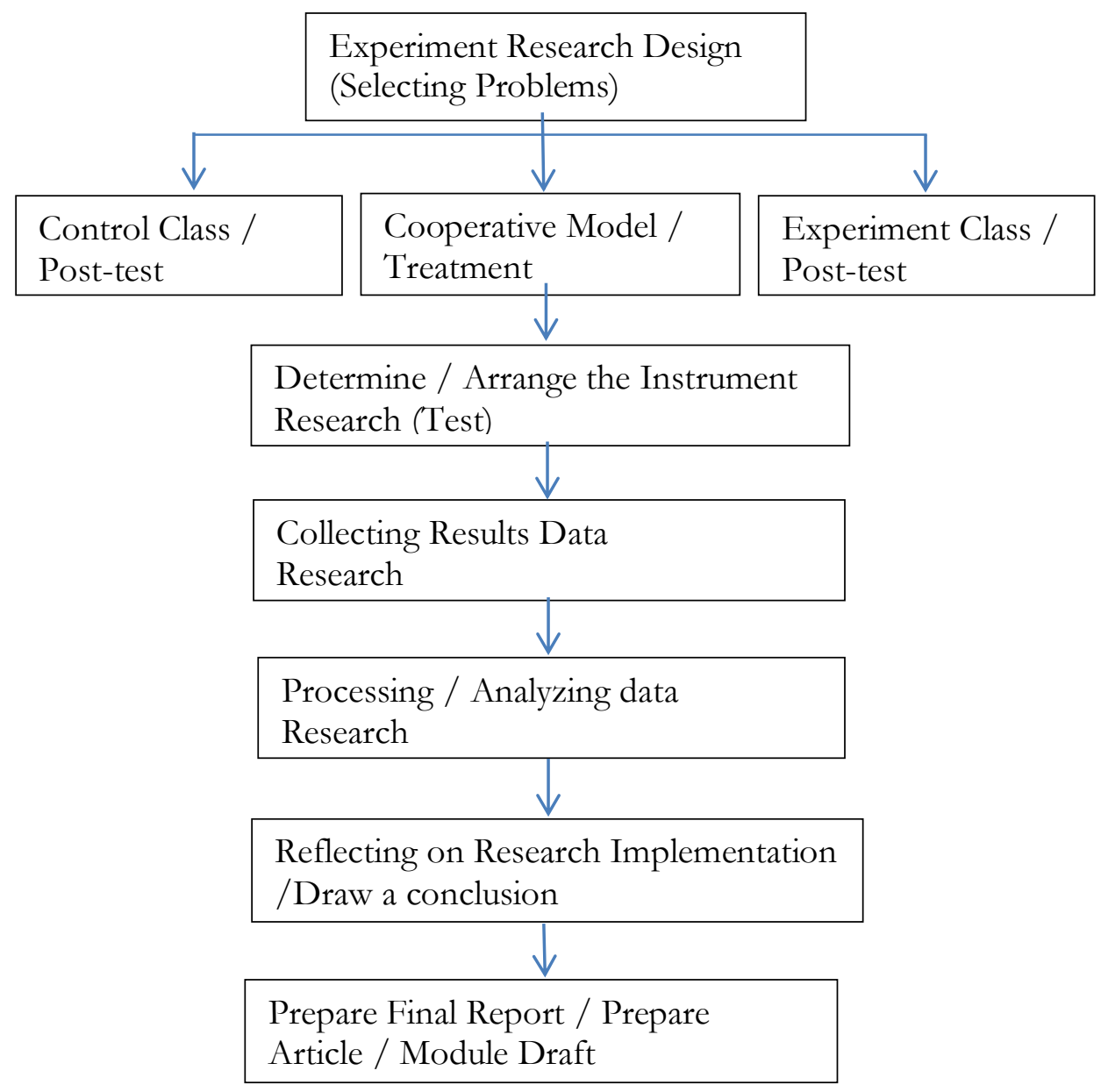




\subsection{Data Collection Techniques}

Data collection technique used in this study was a test. Post-test was conducted on both groups, both the control group and the experimental group. Post-test was conducted to obtain data on teaching materials in General Course of Indonesian language that is on the reasoning of student languages.

\subsection{Data Analysis Techniques}

Data analysis of all research findings in accordance with the focus of the problem and research objectives. Data analyzed were quantitative data that the results of the students' language reasoning ability test. The findings of this data will be compared with predetermined performance indicators. As for the performance indicators determined there was an increase in success students' ability in reasoning language as teaching material for General Course of Indonesian language with cooperative model treatment at Teaching Training and Education Faculty of Muhammadiyah Sumatera Utara University.

\subsection{Indicator of Success}

The indicator used as a measure of success is the first indicator used to show the success of learning is the success of a lecturer in learning and the success of students in participating in learning. The second indicator used to show the success of learning is the learning outcomes of students using cooperative learning models increased compared with students who do not use cooperative learning models or achieve an average value or mean $>75$. This refers to the completeness criteria. In this study, the decision to continue research in other study programs or other faculties, depends on the results of the final reflection of research.

\section{Discussion}

\subsection{Description of Research Results}

The results of the research that have been carried out in the form of language reasoning tests on students of Mathematics Education and Accounting Education in the Teaching Training and Education Faculty of Muhammadiyah Sumatera Utara University semester 4 of the 20182019 academic year can be described as follows.

The value of the language reasoning test results of Mathematics Education students with a sample of 40 students, then obtained the highest value $=90$ as many as 2 students and the lowest value $=50$ as many as 1 student. Students who obtained the value $=85$ were 3 students; value $=80$ as many as 13 students, value $=75$ as many as 7 students, value $=70$ as many as 6 students, value $=65$ as many as 2 students, value $=60$ as many as 2 students and value -55 as many as 4 students.

The value of the reasoning test results in Accounting Education students with a sample of 25 students, then obtained the highest value $=85$ as many as 5 students and the lowest value $=$ 60 as many as 1 student. Students who score $=80$ as many as 5 students; value $=75$ as many as 8 student and value $=70$ as many as 6 students.

\subsection{Discussion of Research Results}

Based on the data of the reasoning test results in 4th semester of Mathematics Education students as described above, it can be described as follows:

Students who get the highest score (90) are 2 students, get 85 points as many as 3 students, get 80 points as many as 13 students, get 75 points as many as 7 students, get 70 points 
as many as 6 students, get 65 points as many as 2 students, get 65 points 60 for 2 students and 55 points for 4 students and 50 points for 1 student.

$\sqrt{ } \sqrt{ } \sqrt{ }$

And from the above data obtained an average value (Mean) $=$ 2940: $40=73.50$. SDX1 $=8.37 . \mathrm{SDX}^{2}=70.03$.

Based on the data of the reasoning test results for 4th semester Accounting Education students as described above, it can be described as follows:

Students who get the highest score (85) are 5 students, get 80 points 5 students, get 75 points 8 students, get 70 points 6 students and get 60 points (lowest) of 1 student.

And from the above data obtained an average value $($ Mean $)=$ 1905: $25=76,20$. SDX2 $=8,96 . \mathrm{SDX}^{2}=80.28$.

Thus, $\mathrm{t}_{\text {count }}=\underline{\mathrm{M} 1-\mathrm{M} 2}$

While $\mathrm{t}_{\text {table }}=1,68$.

$$
\begin{aligned}
& \sqrt{\frac{\mathrm{SDX}^{2}}{\mathrm{~N} 1-1}}-\frac{\mathrm{SDX}_{2}^{2}}{\mathrm{~N} 2-1} \\
& =\frac{76,20-73,50}{3,37-1,79}=\frac{2,70}{1,58}=1,78
\end{aligned}
$$

Statistical test or hypothesis test which states: if $\mathrm{t}$ count is greater than $\mathrm{t}$ table, then $\mathrm{Ha}$ is accepted and $\mathrm{Ho}$ is rejected. If $\mathrm{t}$ count is smaller than $\mathrm{t}$ table, then $\mathrm{Ha}$ is rejected and $\mathrm{Ho}$ is accepted. In this study t count $>\mathrm{t}$ table is $1,78>1.68$. Therefore it can be concluded that there is a significant effect on the use of cooperative learning models in student's language reasoning. In other words, the use of cooperative learning models in Accounting Education can improve language reasoning abilities.

Thus, the use of cooperative learning models in language reasoning as teaching materials of Indonesian language, Teacher Training and Education Faculty, University of Muhammadiyah Sumatera Utara can improve student abilities.

\section{Conclusion}

The conclusion that can be drawn from the results of this study is that there is an increase in the quality of students in terms of language reasoning or in other words the ability of students' language reasoning increases in General Courses of Indonesian language for the academic year 2018-2019, especially Accounting Education Study Program Faculty of Teacher Training and Education Muhammdiyah Sumatera Utara University. Because on the basis of data analysis the results of the student posttest were obtained with Mean $=76.20$ and $\mathrm{t}$ count $=1.78$ and $\mathrm{t}$ table $=$ 1.68 .

Based on the conclusions stated above, the following suggestions are made:

1. Lecturers in Mathematics and Accounting Education study programs, especially lecturers in General Courses of Indonesian language, are advised to innovate learning so that the material for writing scientific papers and language reasoning can be absorbed by students

2. To improve students' language reasoning skills, especially students of Mathematics Education and Accounting Education in order to continuously implement cooperative learning models. 
3. Lecturers that teaching in Mathematics Education and Accounting Education study program are advised to submit the material or teaching material associated with language reasoning (inductive/deductive reasoning).

4. Lecturers of General Courses of Indonesian language who teaches in other study programs at the University of Muhammadiyah Sumatera Utara in order to emphasize the language reasoning material.

\section{References}

Ali, W., T. (2019). Effects of Cooperative Learning Method (CLM) on Vocabularies and Grammars in Essay Writing. Budapest International Research and Critics Linguistics and Education Journal, vol.2 no.2, 27-36.

Alwasilah, C. (2010). Filsafat Bahasa dan Pendidikan. Bandung: Rosda.

Djojosuroto, K. (2007). Filsafat Bahasa. Yogyakarta: Pustaka Book Publisher.

Keraf, G. (2008). Argumentasi dan Narasi. Jakarta: Gramedia.

Keraf, A.,S. (2009). Ilmu Pengetabuan: Sebuab Tinjauan FilsafatYogyakartaKanisius.

Noor, J. (2012). Metodologi Penelitian. Jakarta: Kencana.

Sani, R., A. (2014). Inovasi Pembelajaran. Jakarta: Bumi Aksara.

Sitepu, T. (2005). Bahasa Penalaran dan Penalaran bahasa. Medan: Jurnal Langue. Vol 3 No.2.

Suyitno, I. (2011). Karya Tulis Ilmiah.Bandung: Refika Aditama.

Sudarminta, J. (2008). Epistemologi Dasar: Pengantar Filsafat Pengetahuan. Yogyakarta: Kanisius.

Wijayanti, S., H. et al. (2017). Bahasa Indonesia:Penulisan dan Penyajian karya Ilmiah. Jakarta: Raja Grafindo Persada. 